OPEN ACCESS

Edited by:

Ricardo De La Vega Marcos, Autonomous University of Madrid, Spain

Reviewed by:

Maite Garaigordobil, University of the Basque Country, Spain Nahia Idoiaga,

University of the Basque

Country, Spain

*Correspondence:

Lorea Cortabarria

lorea.cortabarria@ehu.eus

Specialty section

This article was submitted to

Health Psychology,

a section of the journal

Frontiers in Psychology

Received: 30 June 2020 Accepted: 14 September 2020 Published: 11 November 2020

Citation:

Aperribai L, Cortabarria L, Aguirre T,

Verche E and Borges Á (2020)

Teacher's Physical Activity and Mental Health During Lockdown Due to the

COVID-2019 Pandemic.

Front. Psychol. 11:577886

doi: 10.3389/fpsyg.2020.577886

\section{Teacher's Physical Activity and Mental Health During Lockdown Due to the COVID-2019 Pandemic}

\author{
Leire Aperribai $^{1}$, Lorea Cortabarria ${ }^{2 \star}$, Triana Aguirre ${ }^{3}$, Emilio Verche ${ }^{4}$ and África Borges ${ }^{3}$ \\ ${ }^{1}$ Department of Clinical and Health Psychology and Research Methodology, University of the Basque Country UPV/EHU, \\ Donostia-San Sebastián, Spain, ${ }^{2}$ Department of Educational Sciences, University of the Basque Country UPVIEHU, \\ Vitoria-Gasteiz, Spain, ${ }^{3}$ Department of Clinical Psychology, Psychobiology and Methodology, University of La Laguna ULL, \\ San Cristóbal de La Laguna, Spain, ${ }^{4}$ Department of Psychology, School of Biomedical and Health Sciences, Universidad \\ Europea de Madrid, Madrid, Spain
}

The COVID-19 pandemic has led teachers to an unpredictable scenario where the lockdown situation has accelerated the shift from traditional to online educational methods, and relationships have been altered by the avoidance of direct contact with the others, with implications for their mental health. Physical activity seemed to be a factor that could prevent mental disorders such as anxiety or depression in this peculiar situation. Therefore, the aims of this study were to explore how teachers have been affected by the lockdown with respect to their mental health and their relationships in three main fields: work, family, and social relationships, and to know which is the role of physical activity in the mentioned variables. For that purpose, an online survey was designed to collect quantitative and qualitative data. Results showed that indoor physical activity acts as preventive in lockdown situations, whereas the level of activity does not affect mental health. Also, teachers have experienced higher levels of distress due to the workload generated during the lockdown. In conclusion, to prevent health problems among teachers in future similar situations, it would be important to facilitate the practice of physical activity at home. Furthermore, teacher training in blended or online educational methods would be crucial for their favorable work development.

Keywords: CoVID-19, mental health, physical activity, teacher, lockdown

\section{INTRODUCTION}

The global expansion of the COVID-19 pandemic disease has carried out many consequences that may affect people's general health. On the one hand, the virus itself creates personal situations in which, in addition to the disease's symptoms, human emotions such as fear (Asmundson and Taylor, 2020), worry, panic, anxiety, or depression-related distress (Bao et al., 2020) can appear more commonly among people. Indeed, in recent studies about the psychological impact of this pandemic disease on the general population, an increase in depression and stress levels between the first days and the third week of the lockdown has been found (Ozamiz-Etxebarria et al., 2020; Rodríguez-Rey et al., 2020). Furthermore, anxiety has been related to impaired sleep in many studies (Rajkumar, 2020). On the other hand, social situations have changed due to the disease and the subsequent quarantine (Zhang et al., 2020), as well as due to attending to dependent or infected persons or those under other medical conditions at home or nearby. Also, it was due to 
the preventive measures applied by the government such as confinement or lockdown (Liu et al., 2020). In previous pandemics, individual differences seem to play an important role (Asmundson and Taylor, 2020). In any case, broader and more specific research of the impact on mental health is still needed (Mahase, 2020).

Moreover, people worldwide have found themselves coping with new professional scopes (Zhang et al., 2020). Some of them have completely stopped their work, and in brief, they will have to face their future with uncertainty; others have found their work hours increased and have managed risky situations (e.g., health and social workers, or product suppliers). This health crisis is also triggering an economic crisis at a global level and within a few weeks (UNESCO, 2020a).

Another factor influencing adults' personal, social, and professional fields is that related to the lockdown of children at home because, many times, parents have been involved in many roles and tasks at a time (Orte et al., 2020). Meanwhile, educational administrations have not stopped the scholar year, so that teachers have found themselves coping with online education at any level (Wang and Zhao, 2020) while attending to other personal issues. Furthermore, it should be mentioned that Spanish teachers' working conditions before this pandemic situation were already tight due to the teacher/student ratio from 25 to 36 per teacher (Education Youth Policy Analysis Unit in the Education Audiovisual Culture Executive Agency, 2020a) and the high amount of lessons (30-32 per week) they have to give (Education Youth Policy Analysis Unit in the Education Audiovisual Culture Executive Agency, 2020b). Also, all teachers should be prepared in all teaching roles for inclusive education and thus to work with all learners or students in individualized and close relationships, so that they must play a great role in a daily-based work and face-to-face with them. The work becomes even more difficult when this direct contact must be replaced by an online relationship, and many other factors should be considered. Teachers, in general, are not trained for e-learning programs and activities since this is not included in the curriculum of primary and secondary education (Education Youth Policy Analysis Unit in the Education Audiovisual Culture Executive Agency, 2020c). In addition, it should be emphasized that, in crisis situations, teachers may play an additional and crucial role. They can provide psychosocial support to learners. Firstly, teachers can create a safe and supportive interaction where students may express their emotions and experiences; secondly, they can include specific structured psychosocial activities in the teaching/learning process that can strongly help vulnerable students (Inter-Agency Standing Committee, 2007a). Therefore, teachers' workload can be considered quite high, and consequently, the teaching profession can be characterized by high levels of stress and physical complaints (Bogaert et al., 2014).

In the current situation, national governments all around the world are implementing new precautionary and responsive measures on a daily basis to contain the spread of the COVID19 pandemic and to address this crisis that they have established a lockdown situation, social distancing advice, and educational measures such as temporary educational institutions' closures
[European Agency for Special Needs and Inclusive Education, (n.d.)]. These global school closures are impacting over $60 \%$ of the world's student population, and in several countries, the implemented localized closures could impact millions of additional learners (UNESCO, 2020b). Moreover, school closures bring to people of many communities high social and economic costs, impacting mainly the most vulnerable and marginalized children and their families and exacerbating the already existing disparities not only within the education system but also in other aspects of their lives. Teachers also experience an important impact. Firstly, their students are concerned because of the interrupted learning and other collateral effects (disadvantages, lack of opportunities, poor nutrition, social isolation, or lack of care), and this makes even more difficult the teachinglearning process, mainly when parents are not prepared for distance and home schooling or they are not available to attend to their children. Secondly, teachers experience confusion and stress because they are often unsure of their obligations and how to maintain connections with students to support learning. Transitions to distance learning platforms tend to be messy and frustrating, even in the best circumstances. In many contexts, school closures lead to furloughs or separations for teachers. Thirdly, moving learning from classrooms to homes at scale and in a hurry presents enormous challenges, both human and technical (i.e., creating, maintaining, and improving distance learning, or measuring and validating learning) (UNESC, 2020c). In sum, from 1 day to the next, teachers have found themselves creating and managing virtual classrooms, communicating with their students and their parents over social media platforms, and learning by doing as they provide distance education to over 1.5 billion students affected by school closures all over the world due to the COVID-19 pandemic (UNESCO, 2020d). Despite governments' efforts to provide training and resources to support teachers in adapting to this new learning environment, turning from face-to-face to virtual classroom in such a short time has been a challenge as only a few teachers have strong digital and ICT skills. Therefore, in such unprecedented and uncertain times, it is normal for teachers to experience higher levels of stress and anxiety. Teachers need, indeed, socioemotional support to face the extra pressure being put on them to deliver learning in a time of crisis (UNESCO, 2020d). Moreover, providing support for teachers' own psychosocial well-being is an essential component of supporting students (Inter-Agency Standing Committee, 2007b).

Nevertheless, the great changes in students', teachers', and parents' lives around the world caused by COVID-19 have brought to society an opportunity to test its capacity to adapt to sudden stressful situations in which people have been involved in new personal, social, educational, and professional environments and tasks. This health crisis will likely have long-term effects on education, so that it could become an opportunity to rethink the curriculum, teaching-learning assessment processes, and the development of students' competencies while strengthening their learning skills and sustaining their motivation. Moreover, the after-crisis period must be already previewed for the curriculum and learning continuity to be preserved (Daniel, 2020; UNESCO, 2020e). 
This health and, consequently, economic crises caused by a pandemic that is reaching almost all countries in the world within a few weeks are unprecedented in the recent past. But lessons might be drawn from previous epidemics and economic crises (UNESCO, 2020a). It can be concluded from previous experiences that physical activity and exercise could help to mitigate the effects caused by the current pandemic on the mental and physical health of citizens worldwide. Being physically active should be highly recommended (Amatriain-Fernández et al., 2020) considering that physical activity could help in preventing psychological or mood disorders (Kwan et al., 2012) and improving the quality of life by decreasing the negative psychosocial effects of lockdown due to the COVID-19 pandemic (Slimani et al., 2020). In the same way, the role of physical activity in general health and well-being of teachers during lockdown should be important also, as it has been found that those teachers performing more exercise during leisure time, or in a more autonomous way, may prevent easier physical and mental health problems (Bogaert et al., 2014). In order to lead toward an aftercrisis scenario and to prevent negative effects in future possible crises, it is worthy to know how these factors act in this lockdown situation. Therefore, this study aims to explore how teachers have been affected by the lockdown with respect to their mental health and their relationships in three main fields, such as work, family, and social relationships. Another objective followed by the study is to know which is the role of physical activity in the mentioned variables.

\section{MATERIALS AND METHODS}

\section{Method and Design}

A mixed methods design, known as the third paradigm (Johnson and Onwuegbuzie, 2004; Denscombe, 2008), has been used. It is characterized for including in the same research both quantitative and qualitative methods, specifying in the design the weight and the sequence of each part and explaining how both approaches are linked (Creswell and Plano Clark, 2011). The applied design, the so-called concurrent triangulation, gives the same weight to qualitative and quantitative data (Smith et al., 2016).

\section{Participants}

The sample of this research was composed of 345 teachers with a mean age of 44.62 years $(S D=9.53 ; 264$ women; 80 men; 1 preferred not to say) currently teaching in Spain in primary and secondary education (see Table 1). Most of the teachers were

TABLE 1 | Participants' frequencies considering the educational levels in which they teach.

\begin{tabular}{lcc}
\hline Educational Level & Frequency & $\%$ \\
\hline Primary education (6-12 years old) & 71 & 20.58 \\
Secondary education (12-16 years old) & 77 & 22.32 \\
Postcompulsory secondary education (16-18 years old) & 17 & 4.93 \\
Others (i.e., languages, sports, arts) & 53 & 15.36 \\
More than one level & 127 & 36.81
\end{tabular}

working in public schools $(\mathrm{n}=258)$, while 52 were in private schools and 35 in state-funded private schools.

\section{Instruments}

Data were collected using a questionnaire that included information about sociodemographic variables, teaching working conditions, and outdoor and indoor physical activities by using specific questions that were analyzed as quantitative variables. The Spanish version of the GHQ-12 (Sánchez-López and Dresch, 2008) was applied to measure mental health with the permission of the authors. This one-dimensional 4-point (0-3) Likert scale is composed of 12 items measuring aspects related to social dysfunction, anxiety, and depression. The questionnaire has acceptable psychometric properties, being its internal consistency acceptable $(\alpha=0.76)$. Its external validity has been assessed by correlating with the ISRA's anxiety questionnaire, being the correlation with the whole scale medium $(r=0.57)$ and the correlation with the ISRA's factors high: Factor I $r=0.82$; Factor II $r=0.70$; and Factor III $r=0.75$ (Sánchez-López and Dresch, 2008). Finally, open questions were applied to collect qualitative data about working conditions, family, and relationships.

\section{Procedure}

Once the University of La Laguna's Ethics Committee's (CEIBA) approval [CEIBA2020-0401] and the permission of the authors of the Spanish version of GHQ-12 were obtained, a Google Form questionnaire with the mentioned sociodemographic, work, and physical activities' variables, the GHQ-12 scale, and the open questions (in this order) was created and sent to the participants. These were recruited by following a non-probabilistic snowball sampling procedure. For that purpose, social network was used, and corporate emails were sent in the first 3 weeks of the lockdown to Spanish teachers so that data were collected between the last week of April and the first week of May in 2020, during the lockdown and the 0 Phase when people had strong restrictions for outdoor activities and after 6 weeks that online education was established at all educational levels. All participants provided the informed consent to participate in the study. Therefore, the study fulfills the Declaration of Helsinki and the Organic Law 3/2018, of the 5th December, about Personal Data Protection and digital rights' warranty.

\section{Data Analyses}

Firstly, descriptive statistics were performed. Secondly, Cronbach's alpha was estimated to analyze the reliability index of the GHQ-12 scale. Thirdly, to analyze the effect of physical activity with $t$-test, the participants were divided into two groups, differentiating between those who performed less and more physical activity. The first group was composed of those who practice little physical activity, that is, $3 \mathrm{~h}$ maximum per week; the second group was composed of those who practice more than $4 \mathrm{~h}$ of physical activity per week. Quantitative analyses were carried out by using the JASP software (JASP Team, 2020). Fourthly, quantitative information was triangulated to explore which were the best predictors of mental health by analyzing the contribution that the variables physical activity hours (outdoor and indoor) and teaching performance hours, as 
TABLE 2 | Descriptive statistics of the GHQ-12 scale.

\begin{tabular}{|c|c|c|c|c|c|c|c|c|c|c|c|c|c|}
\hline & GHQTotal & GHQ1 & GHQ2 & GHQ3 & GHQ4 & GHQ5 & GHQ6 & GHQ7 & GHQ8 & GHQ9 & GHQ10 & GHQ11 & GHQ12 \\
\hline Mean & 22.05 & 1.96 & 2.08 & 1.66 & 1.74 & 2.25 & 1.88 & 2.02 & 1.87 & 1.91 & 1.71 & 1.39 & 1.58 \\
\hline Std. Deviation & 5.26 & 0.62 & 0.89 & 0.87 & 0.75 & 0.93 & 0.82 & 0.83 & 0.67 & 0.90 & 0.82 & 0.93 & 0.89 \\
\hline
\end{tabular}

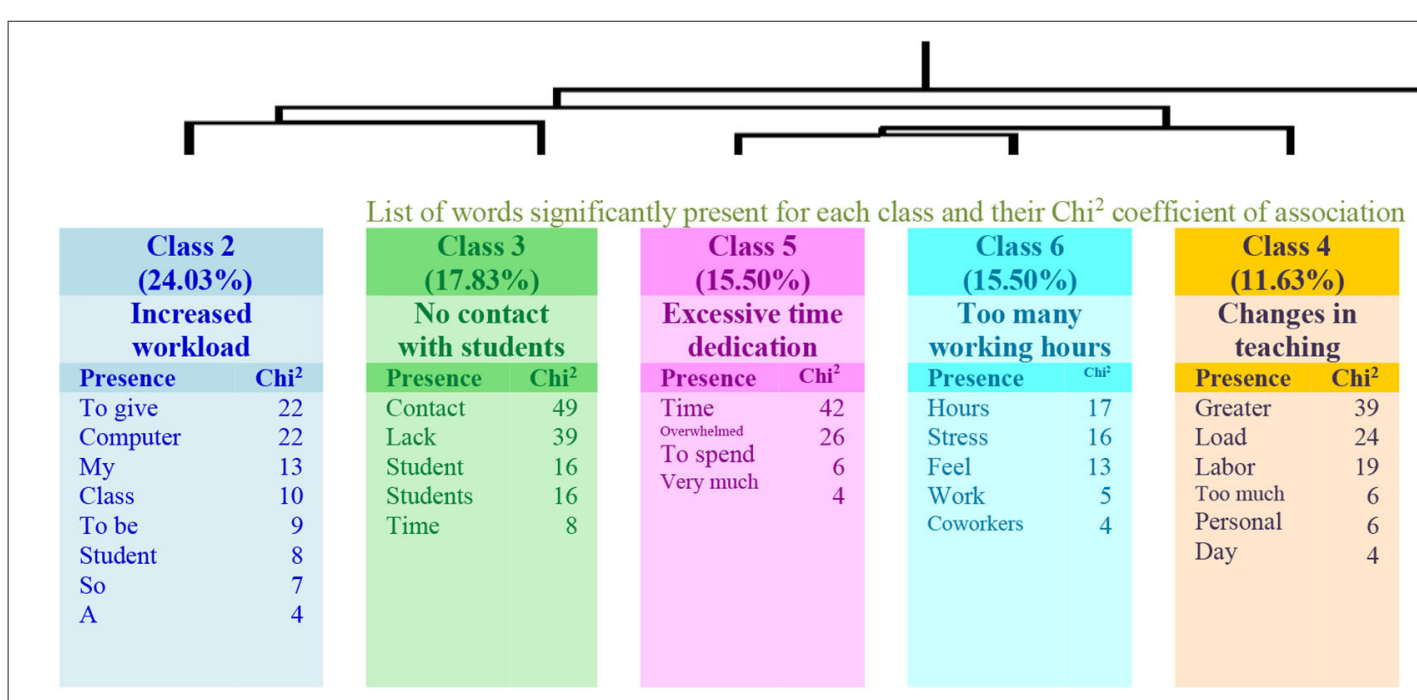

FIGURE 1 | Dendrogram for Question 1: "What changes do you observe regarding your professional performance? How do you feel about it?" (Low physical activity).

well as the number of students, have into the teachers' mental health with a Bayesian regression model. Fifthly, the perception that participants of both groups had about the changes that the lockdown situation had brought to the family, work, and social relationships was studied. Qualitative data obtained from the open questions were analyzed with the ALCESTE software (Lexical Analysis of Co-occurrences in Simple Text Statements; Reinert, 2001). This software uses statistical procedures to extract essential information from a text by receiving essential information, quantifying its strongest lexical structures, and grouping the co-occurrence, this last being the association by proximity of various words (nouns, adjectives, or verbs) using the chi-square statistic, with the aim of differentiating the most significant lexical words. Those words showing chi-squares higher than 3.841 were retained, following Camargo and Bousfield (2009) criterion. The analyzed unit is the elementary context unit (ECU), which corresponds to the idea of a sentence or a set of between 8 and 20 words (De Alba, 2004). One of the advantages of this approach is that it avoids the subjectivity involved in the construction of categories by the researcher, since the computer program establishes the connections using statistical procedures (Bauer, 2003).

\section{RESULTS}

\section{Descriptive Results of Teaching and Physical Activities and Reliability of the GHQ-12 Scale}

On the one hand, participants admitted that they spent an average mean of $38.34 \mathrm{~h}(S D=19.28 \mathrm{~h})$ per week doing teaching activities. Regarding online activities, $64.34 \%(n=182)$ manifested to have previously none or a little training in virtual teaching, and $56.81 \%(n=196)$ participants claimed to do quite or much training on how to teach online during the lockdown.

On the other hand, in relation to physical exercise, $80 \%$ of the participants $(n=276)$ stated that they did physical exercise at home $\left(M_{\text {Hours } / \text { week }}=4.12 ; S D=4.063\right)$, and $57.39 \%(n=198)$ admitted that they went for a walk $\left(M_{\text {Hours } / \text { week }}=1.69 ; S D=2.381\right)$.

Considering the teachers' general health, the average mean of the GHQ-12 total scores was $22.05(S D=5.26)$ (see descriptive statistics in Table 2). Moreover, the GHQ-12 scale showed an acceptable reliability index (Cronbach's $\alpha=0.77$ ). Finally, when comparing the GHQ-12 total scores between teachers doing high physical activity $(n=141 ; M=21.596$; $S D=5.426)$ and low activity $(n=204 ; M=22.368 ; S D$ $=5.128)$, statistically significant differences were not found $(t(343)=1.34 ; p=0.1809)$. The effect size was small (Cohen's $d=0.1468)$.

\section{Predictors of Mental Health: Bayesian Linear Regression}

A Bayesian linear regression was carried out considering as predictors of the GHQ-12 score the amount of hours of physical activity performed at home, the hours dedicated to teaching performance, the number of students, and the number of hours spent walking away from home. An uninformed uniform prior $[\mathrm{P}(\mathrm{M})]$ of 0.063 was set for each possible model. The results suggest that the best regression model is the one including the time of physical activity at home and the hours dedicated to teaching work $(B F 10=11.07)$ compared to the null model. The 


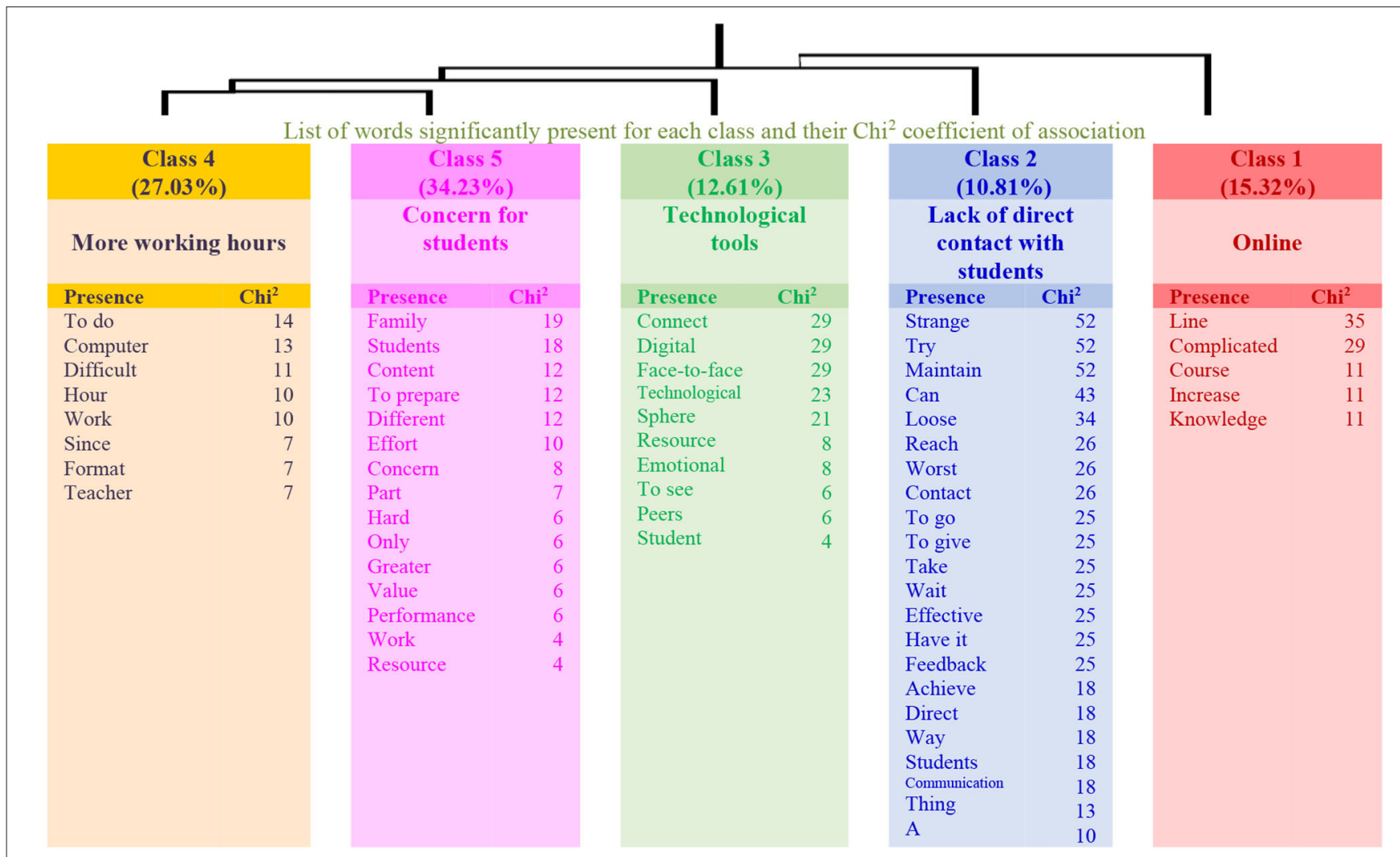

FIGURE 2 | Dendrogram for Question 1: "What changes do you observe regarding your professional performance? How do you feel about it?" (High physical activity).

regression coefficient for hours of physical activity at home is $b_{1}$ $=-0.096$ and for teaching work $b_{2}=0.039$. The constant of the model is $b_{0}=22.052$. For instance, a teacher that is doing $5 \mathrm{~h}$ of physical activity a week and working for $39 \mathrm{~h}$ a week will have a mental health score of 21.9929 (see the equation below) measured with the GHQ-12.

$$
\begin{aligned}
& y=22.052+(-0.096 \times[5-4.118]) \\
& +(0.039 \times[39-38.345])=21.9929
\end{aligned}
$$

\section{Perception of the Changes Experienced Due to the Lockdown Situation}

The responses given about the changes found in the lockdown situation have been analyzed through the ALCESTE program in three areas: work, family, and social relationships. Considering that we have not found statistically significant differences in mental health between teachers with high and low levels of physical activity, and aiming to know what teachers from different levels say about the before mentioned areas, answers to three open questions have been analyzed on the basis of the high and low levels of physical activity, as presented below.

\section{Question 1: Changes Observed by Teachers Regarding Their Professional Performance ("What Changes Do you Observe Regarding Your Professional Performance? How Do you Feel About It?")}

On the one hand, in the analysis made for the low physical activity group, six factors or classes explaining $59 \%$ of the textual units were obtained (see the dendrogram in Figure 1). The first class (Changes in professional life) shows a more general content and connects with other two classes, 2 (Increased workload) and 3 (No contact with students), that are related to the way of teaching and to the contact with the students. The link between classes 2 and 3 connects with class 4 (Changes in teaching) and the link between classes 5 (Excessive Time Dedication) and 6 (Too many working hours). These classes have in common the shared complaint of working in excess and dedicating more hours due to the changes in teaching strategies.

On the other hand, in the analysis made with the answers given by the teachers with higher levels of physical activity to the same question, a different structure emerges, this time composed of five factors or classes that explain 54\% of the textual units but that are also organized in a more hierarchical structure. In this respect, the first class (Online) connects with class 2 (Lack of direct contact with students). The second connects with class 3 (Technological tools), and the third connects with 
TABLE 3 | Information of Question 1: "What changes do you observe regarding your professional performance? How do you feel about it?"

\begin{tabular}{lllll}
\hline Class & $\chi^{2}$ & ECU & $\%$
\end{tabular}

\section{Low physical activity group}

Sentences

Sentences

11

10

3

Sentences

15

14

11

4

Sentences

17

17

13

5

Sentences

23

21

13

6

Sentences

\section{Changes in professional life}

20

Obviously, the treatment with coworkers and students is different, I feel that I need them to improve as a professional, I also see this circumstance as a challenge in order to improve at a professional level [evidentemente, el trato con los compañeros y el alumnado es diferente, me siento que necesito de ellos para mejorar como profesional, además veo esta circunstancia como un reto a nivel profesional para poder mejorar]

$30 \quad$ Need for online training. Maybe we are closer [necesidad de formación online. estamos más unidos igual]

28 All changes unleashed at a professional level are negative, because I feel that I have lost what gives meaning to my work: dealing with students [los cambios que ha desencadenado a nivel profesional son todos negativos, pues siento que he perdido lo-que da sentido a mi trabajo: el trato con el alumnado]
Increased workload
31
24.03
To give [Dar]

The workload has increased greatly. In some groups the way of teaching is quite ineffective, so that they require a live and in-person explanation [la carga de trabajo se ha intensificado muchísimo. la manera de dar clase es bastante inefectiva en algunos cursos, ya que requieren de una explicación en directo y en persona]

Care for my children, give more, prepare them more [la atención a mis niños, dar más, prepararlos más]

Full-time online teaching is an activity that requires being in front of the computer for $10 \mathrm{~h}$ a day. It is horrible [la docencia online a jornada completa es una actividad que requiere estar delante del ordenador 10 horas diarias. es horroroso]
No contact with students
23
17.83
Contact [Contacto]

\section{Lack of contact with students [falta de contacto con los alumnos]}

Overflowed with so much work. There is no time limit. Given the lack of information, with uncertainty about how I will address the end of the course as a counselor [desbordada con tanto trabajo. no hay límite horario. con incertidumbre respecto de cómo voy a abordar el final de curso como orientadora dada la falta de información]

1 Isolation, less teamwork, lack of student contact. Sometimes frustrated [aislamiento, menos trabajo en equipo, falta de contacto alumnado. frustrada a veces]
Changes in teaching
15
11.63
Greater [Mayor]

Extension of the working day. Cancellation of days off, holidays. Exploited [extensión de la jornada laboral. anulación de días libres, vacaciones. explotado]

Greater labor disorganization feeling of greater personal worth [ mas trabajo en equipo, generando sensación de mayor valia persona] Greater labor disorganization and greater tension due to both legislative and lockdown time uncertainty [mayor desorganización laboral y mayor tensión debido a la incertidumbre tanto legislativa como de tiempo de confinamiento]
Excessive time dedication
20
15.50
Time [Tiempo]

I feel that I have to spend much more time. Overwhelmed [siento que tengo-que dedicar mucho más tiempo. agobiada] I keep spending a lot of time [le sigo dedicando mucho tiempo]

I spend much more time. Overwhelmed by not having that time for personal issues [empleo mucho más tiempo. agobiada por no contar con ese tiempo para temas personales]
Too many working hours
20
15.50
Hour [Hora]

$7 \quad$ More working hours [más horas de trabajo]

$7 \quad$ I work $24 \mathrm{~h}$. I started to dose them [trabajo las 24 horas. estoy empezando a dosificarlo]

7 I work many more hours and I feel that I cannot disconnect my work sphere from the family [trabajo muchas más horas y siento que no puedo desconectar mi ambito laboral del familiar]

\section{High physical activity group}

\begin{tabular}{|c|c|c|c|c|c|}
\hline \multirow[t]{3}{*}{ Sentences } & 107 & \multicolumn{4}{|c|}{$\begin{array}{l}\text { I have been able to increase my knowledge about online courses. I feel good [he podido aumentar mi conocimiento con cursos en } \\
\text { linea. me siento bien] }\end{array}$} \\
\hline & 67 & \multicolumn{4}{|c|}{ Online education is complicated. Quiet [lo complicado de la educación online. Tranquila] } \\
\hline & 16 & \multicolumn{4}{|c|}{ Online life, always at computer [vida online, siempre ordenador] } \\
\hline 2 & & Lack of direct contact with students & 12 & 10.81 & Strange [extraño] \\
\hline \multirow[t]{3}{*}{ Sentences } & 31 & \multicolumn{4}{|c|}{$\begin{array}{l}\text { Not maintaining direct contact makes you see things differently, and you try to manage everything differently. It is a bit strange to } \\
\text { teach children without being them in front of you [no mantener contacto directo hace ver las cosas de otra manera, y se intenta } \\
\text { gestionar todo de manera distinta. resulta un poco extraño dar clases a niños sin poder tenerlo en frente] }\end{array}$} \\
\hline & 26 & \multicolumn{4}{|c|}{$\begin{array}{l}\text { Not going to school is strange. Sometimes I feel like losing time, even when I try to maintain communication with the students, it is } \\
\text { not even possible to reach 50(\%) [no ir a la escuela es extraño. A veces lo siento como tiempo perdido aun cuando se intenta } \\
\text { mantener comunicación con los estudiantes no se logra llegar ni-siquiera a un 50] }\end{array}$} \\
\hline & 18 & \multicolumn{4}{|c|}{$\begin{array}{l}\text { Not being able to have contact with the students is what I take the worst. Feedback is not immediate, so you have to wait them to } \\
\text { read and write, it is less effective for them [el no poder tener contacto con los alumnos es lo-que peor llevo. el feedback no es al } \\
\text { momento, sino que hay que esperar a que lo lean y escriban, es menos efectivo para ellos] }\end{array}$} \\
\hline
\end{tabular}


TABLE 3 | Continued

\begin{tabular}{|c|c|c|c|c|}
\hline Class & $\chi^{2}$ & ECU & $\%$ & Word \\
\hline 3 & & Technological tools & 12.61 & Connect [Conecta] \\
\hline \multirow[t]{3}{*}{ Sentences } & 46 & \multicolumn{3}{|c|}{$\begin{array}{l}\text { Obstacles for connecting emotionally with adolescent students and competitiveness among peers to see who is the most } \\
\text { technological, intoxication due to digital resources [obstáculos a la hora de conectar en el plano emocional con los alumnos } \\
\text { adolescentes y competitividad entre compañeros por ver quién es el más tecnológico/ a, intoxicación de recursos digitales] }\end{array}$} \\
\hline & 11 & \multicolumn{3}{|c|}{$\begin{array}{l}\text { The development of the non-face-to-face session and trying to cover as much as possible with technological and strategic tools that } \\
\text { allow me to achieve compliance effectively [el desarrollo de la sesión no presencial y tratando de abarcar lo más posible con } \\
\text { herramientas tecnológicas y estratégicas que me permitan lograr cumplir de manera eficaz] }\end{array}$} \\
\hline & 9 & \multicolumn{3}{|c|}{ Material resources and the face-to-face part [recursos materiales y la parte presencial] } \\
\hline 4 & & More working hours & 27.03 & To do [Hacer] \\
\hline \multirow[t]{3}{*}{ Sentences } & 17 & \multicolumn{3}{|c|}{ More hours at the computer, more working hours [más horas al ordenador, más horas de trabajo] } \\
\hline & 11 & \multicolumn{3}{|c|}{$\begin{array}{l}\text { Complicated to correct activities since I am a plastic art teacher and the technical drawing exercises take me hours to correct when } \\
\text { they could be corrected in much less time in print format [me es muy complejo corregir las actividades ya que soy de plástica y el } \\
\text { dibujo técnico me lleva horas corregir ejercicios que se podrían corregir en mucho menos tiempo de forma impresa] }\end{array}$} \\
\hline & 11 & \multicolumn{3}{|c|}{$\begin{array}{l}\text { More eyestrain since hours in front of the computer have increased [más cansancio visual ya que han aumentado las horas delante } \\
\text { del ordenador] }\end{array}$} \\
\hline 5 & & Concern for students & 34.23 & Family [Familia] \\
\hline \multirow[t]{3}{*}{ Sentences } & 14 & \multicolumn{3}{|c|}{$\begin{array}{l}\text { You work for more hours and sometimes you feel overwhelmed not only for preparing the classes, but for finding different resources } \\
\text { to support a better understanding of the content and for helping families emotionally. Sometimes it is hard [se trabaja más horas y a } \\
\text { veces te sientes agobiada pues no solo preparar las clases, sino buscar distintos recursos para apoyar un mejor entendimiento de } \\
\text { los contenidos y ayudar a las familias emocionalmente a veces es duro] }\end{array}$} \\
\hline & 14 & \multicolumn{3}{|c|}{ My main concern is the assessment of students [Mi mayor preocupación es la evaluación de alumnado] } \\
\hline & 8 & \multicolumn{3}{|c|}{$\begin{array}{l}\text { The effort is not valued and it is better valued to be more a bum who sends and corrects a task and does not worry about students } \\
\text { learning or doing well [que no se valora todo el esfuerzo y que se valora ser más un vago que manda una tarea y su corrección y no } \\
\text { se preocupa porque su alumnado aprenda o esté bien] }\end{array}$} \\
\hline
\end{tabular}

the link of classes 4 (More working hours) and 5 (Concern for students). Therefore, teachers who have higher levels of physical activity express opinions about the consequences of online teaching during the lockdown, but these are weakly linked (see the dendrogram in Figure 2).

Table 3 presents the analyses carried out in the two groups, specifying the name of each class, the number of the elementary context units (ECUs) and their explained percentage, as well as the more representative word. The three examples with the highest $\chi^{2}$ are also shown for each class.

\section{Question 2: Changes Observed by Teachers in Their Family Lives Due to the Lockdown ("What Changes do you See in Your Family Life? How do you Feel About it?")}

Teachers were asked about the changes they observed in family life as a consequence of the newly applied online teaching methods due to the pandemic. In the group with a low physical activity, a structure of three classes explaining $48 \%$ of the textual units emerges (see the dendrogram in Figure 3). The first class (Little time for the family) is connected to the link between the classes 2 (Telecommuting) and 3 (Less contact with the family). Therefore, teachers perceive a decrease in the contact with their family member that could be related to telecommuting and the consequent increase in the workload.

Regarding those teachers with higher levels of physical activity, the changes observed in family life were explained in three classes with $45 \%$ of the textual units (see the dendrogram in Figure 4). Class 1 (Dedication to the family) connects with the link established by classes 2 (Isolation from the family) and 3 (Changes in family life). Thus, teachers with higher levels of physical activity manifest a decrease in the contact with family members but do not relate to the workload.

The results related to the analyses carried out regarding the changes observed in family life are shown in Table 4. The table specifies the name of each class, the number of the elementary context units (ECUs) and their explained percentage, as well as the more representative word. The three examples with the highest $\chi^{2}$ are also shown for each class.

\section{Question 3: Changes Observed by Teachers in Their Interpersonal Relationships ("What Changes do you See in Your Interpersonal Relationships? How do you Feel About it?")}

Regarding the answers to Question 3 in the group of lower levels of physical activity, four classes explaining $45 \%$ of the textual units have been obtained (see the dendrogram in Figure 5). In this structure, class 1 (Need for physical contact) connects with class 2 (Online relationships), and with the link between classes 3 (Distance relationships) and 4 (Distance with friends). Thus, teachers perceive distance despite the online relationship, and they miss physical contact in their relationships.

As for the group with higher levels of physical activity, the answers are grouped into four classes explaining 38\% of the textual units (see the dendrogram in Figure 6). In this structure, class 1 (Difficulties to contact friends) connects with class 2 (Quality of interpersonal relationships), and with the link between classes 3 (Greater contact) and 4 (Greater online 


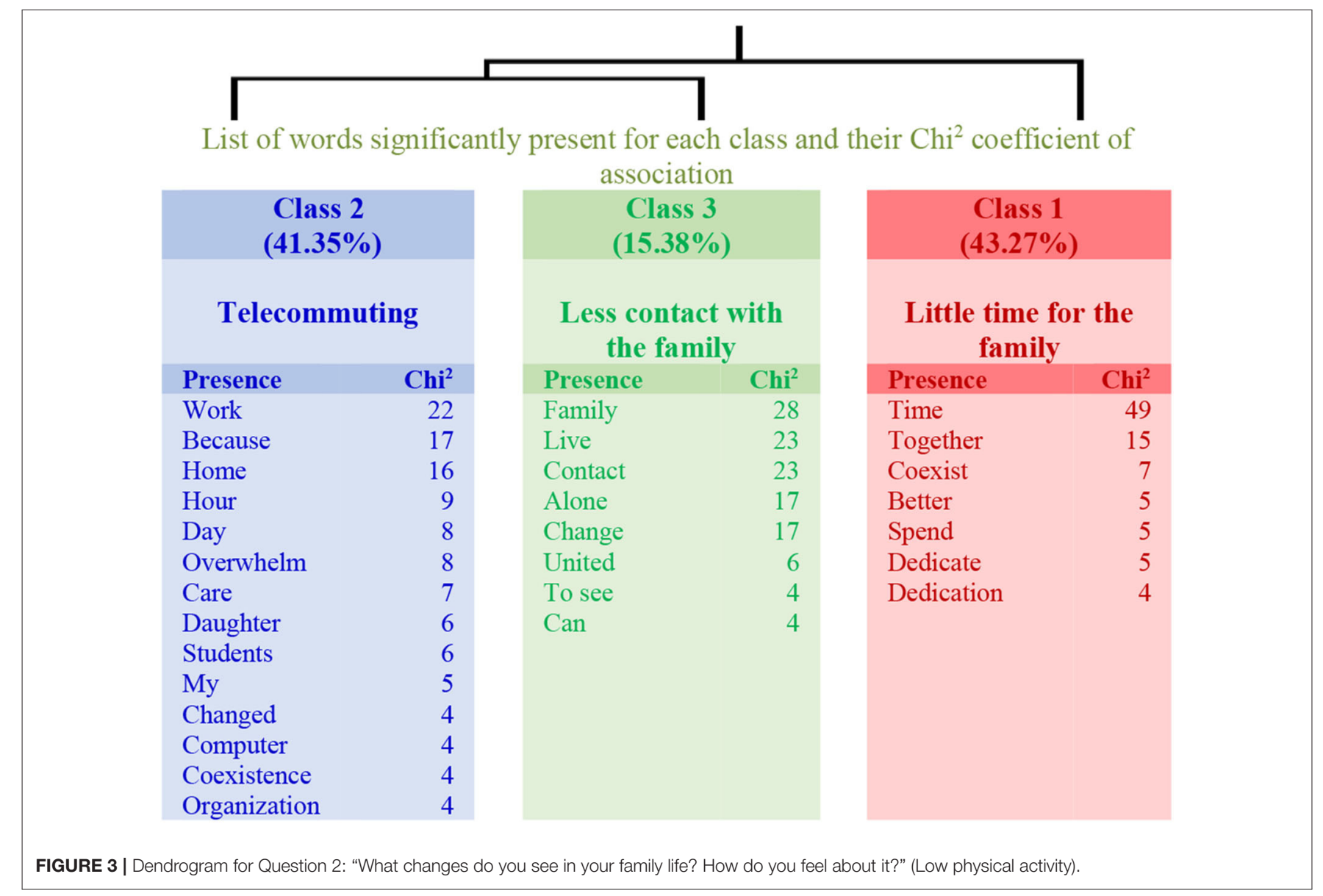

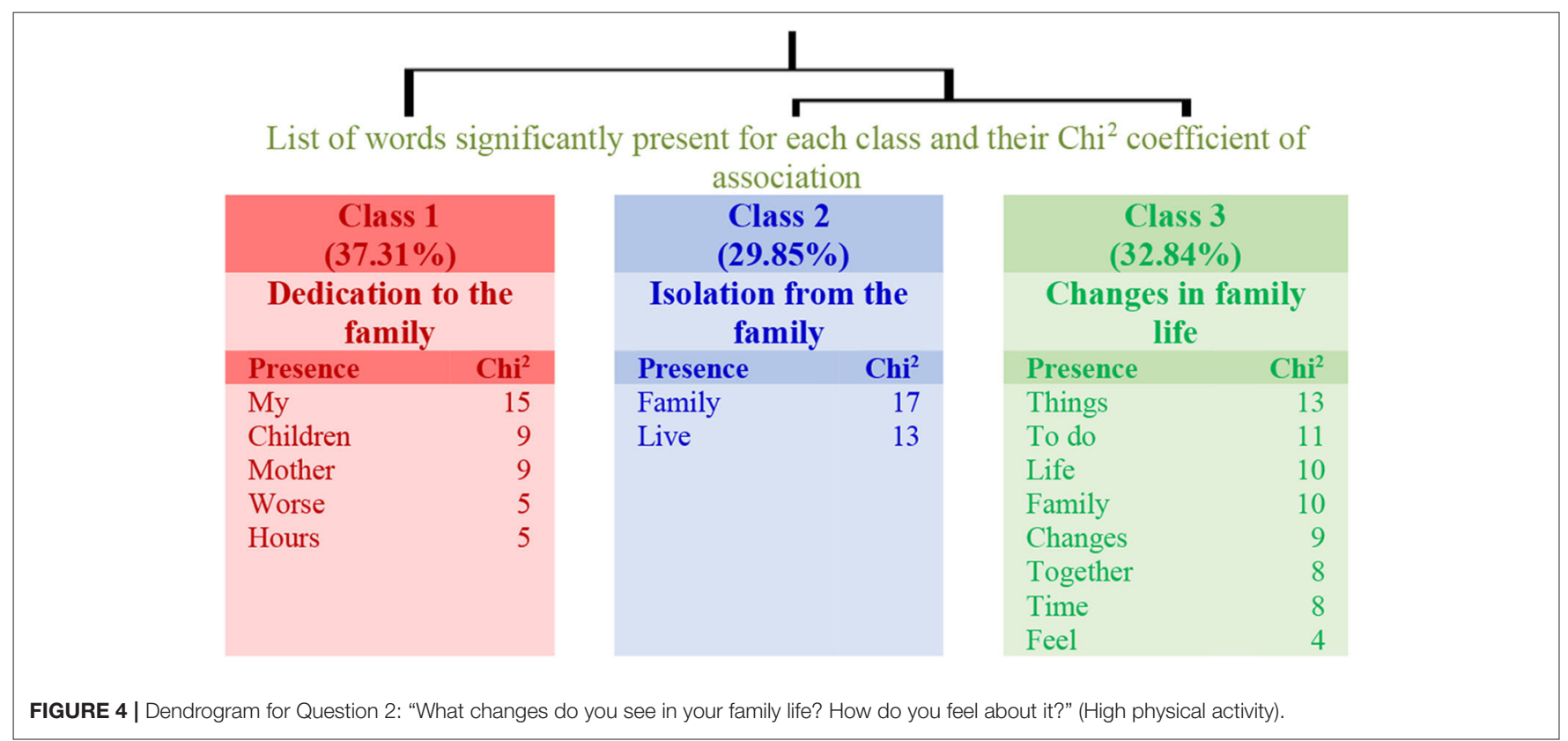

contact). Therefore, teachers with higher levels of physical activity perceive greater contact but also difficulties and a loss of quality in their relationships.
Table 5 presents the detail of the analyses carried out in terms of the name of each class, the number of the ECUs and their explained percentage, and the more representative 
TABLE 4 | Information of Question 2: "What changes do you see in your family life? How do you feel about it?"

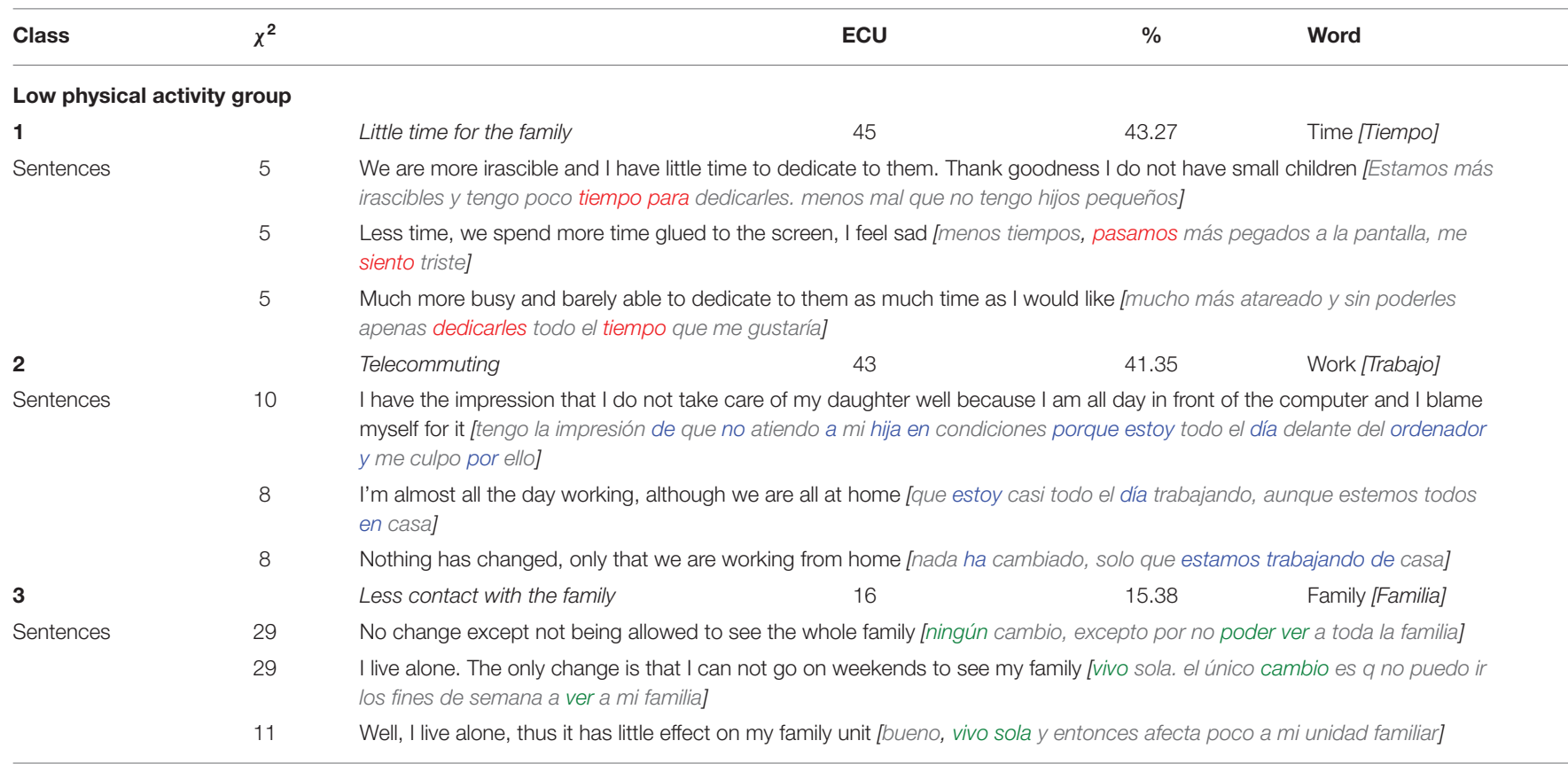

\section{High physical activity group}

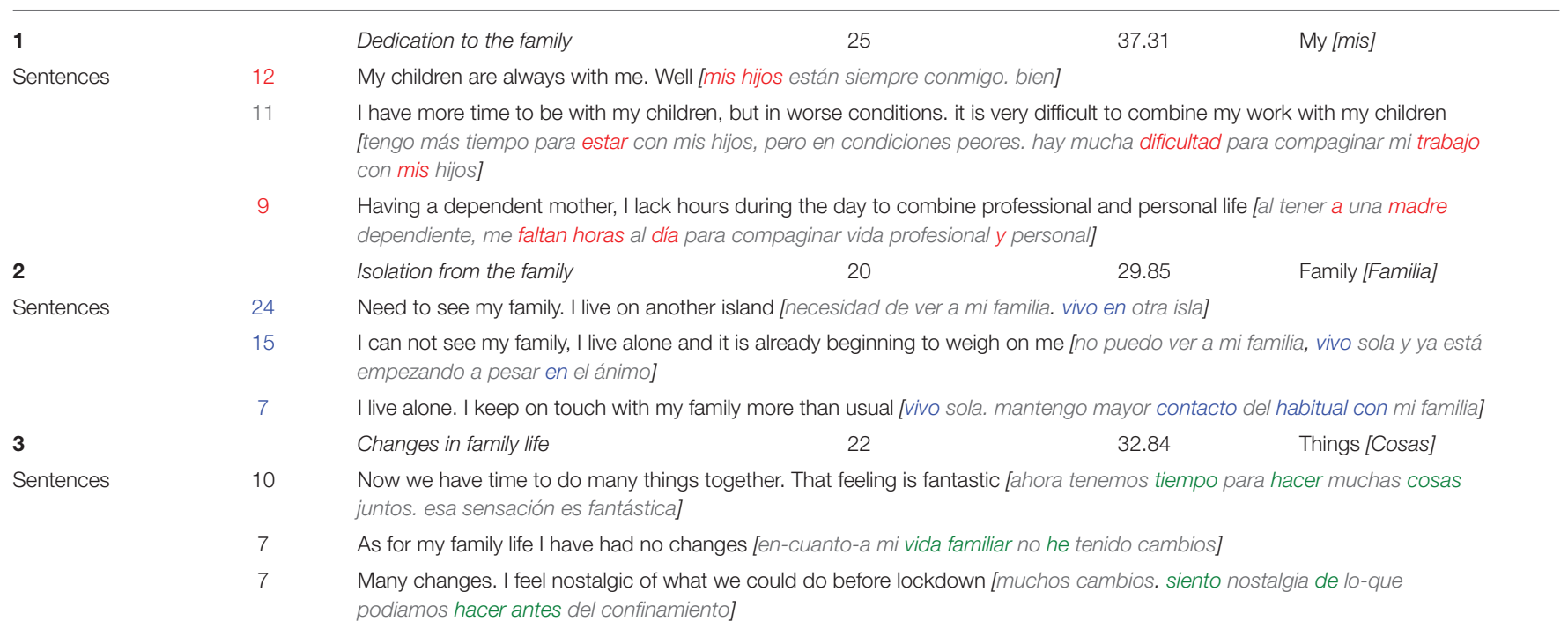

word, together with three examples of the highest values of $\chi^{2}$.

\section{DISCUSSION}

The GHQ-12 scale measures state and not trait because items refer to how the participant perceives itself these days. In some studies, scores above 12 have been considered as indicating the existence of an emotional disorder (Ruiz et al., 2017). The average score of the sample $(M=22.05 ; S D=5.26)$ indicates symptoms of emotional problems. In case we were not experiencing the special situation of lockdown and the stress that this implies, a detailed clinical evaluation would be recommended.
These emotional problems are predicted negatively by the time devoted to physical activity weekly and positively with the number of hours working on teaching activity. Physical activity has been seemed to be a protector in developing emotional problems in this study and in previous (Kwan et al., 2012; Bogaert et al., 2014; Amatriain-Fernández et al., 2020), but in this study, the level of activity in general does not make the difference, while it seems that the type of activity, specifically indoor physical activity, explains part of the variance on mental health; thus, it should be enhanced in order to improve teachers' mental health. However, other possible stressors such as the number of students seem to have no relationship with mental health. Nonetheless, the predictor power of these variables is weak, so other variables 


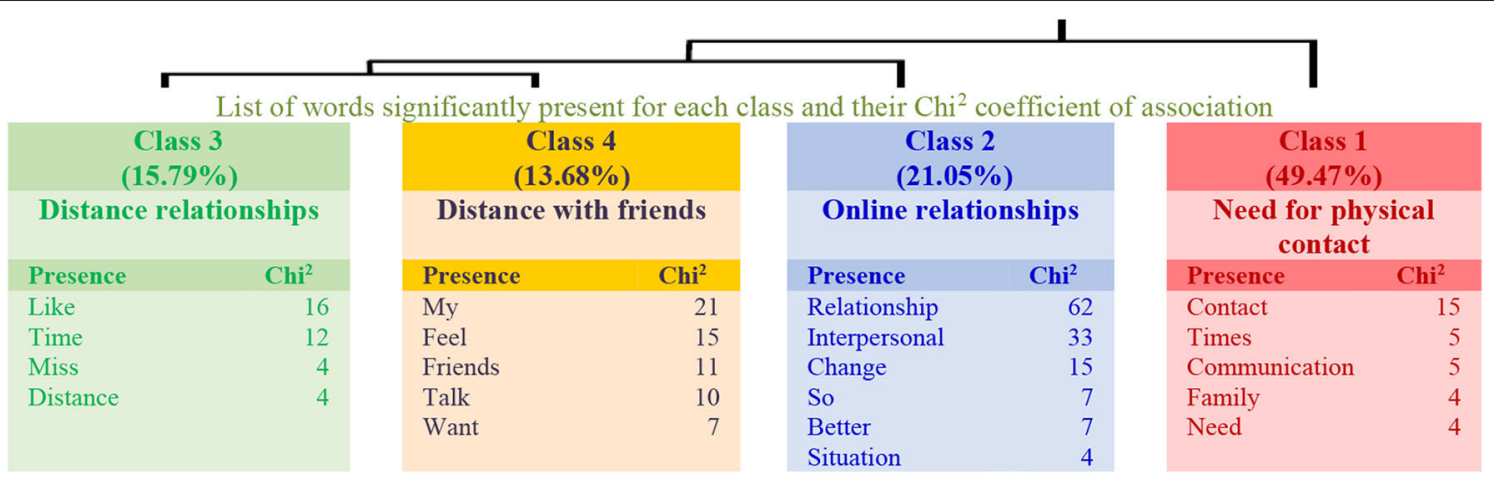

FIGURE 5 | Dendrogram for Question 3: "What changes do you see in your interpersonal relationships? How do you feel about it?" (Low physical activity).

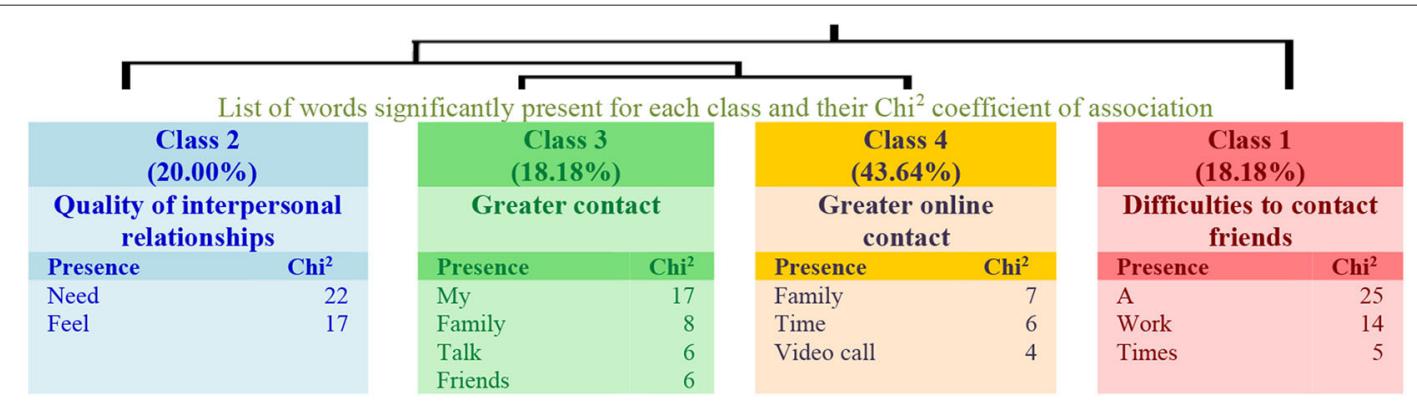

FIGURE 6 | Dendrogram for Question 3: "What changes do you see in your interpersonal relationships? How do you feel about it?" (High physical activity).

should also be considered to be studied as predictors of mental health in teachers.

The results extracted from the qualitative responses show differences related to the observed changes in teachers' lives due to lockdown. Clear differences are observed in the discourse of the two groups of teachers. On the one hand, those who report having low physical activity point out changes in their professional lives and in their relationship with students and focus on showing their concern for the greater dedication and longer working time required by online teaching. On the other hand, teachers who have more time to develop physical activity show a greater dispersion in their responses. In this respect, two classes are related to their relationship with students, the other two have to do with changes or challenges in their teaching performance (the change to online teaching and the need to master technological strategies), and the last one is related to the expression of opinions regarding the increased workload. This aspect has already been included in the literature, since telecommuting is more demanding in hours, due to the fact that the environment does not change, along with having to put into play new skills that they were lacking on a regular basis (Santillán, 2020).

Despite the fact that work changes determinate modifications in family life, which are included in two classes in the low physical activity group and in three classes in the other group, in both groups, to spend more time with the family has been considered as a positive indicator. In other words, both groups regret the difficulty they have to meet with the family due to the lockdown.

Social relationships have also been affected by the lockdown. In this section, the opinions expressed by the group with greater physical activity are more optimistic than those manifested by the group with little physical activity. In the first group, the distance feeling is mentioned only in one class, while the other expressions indicate a positive attitude, considering the value of maintaining online relationships. Meanwhile, the group with lower levels of physical activity manifests complaints related to the lack of relationships in all classes. Further research should be addressed to know more about the type of physical activity or other variables that improve mental health.

The main limitation of this work is that it has not been possible to cover a more specific regional and a broader international perspective. Another limitation is that other variables related to working and personal conditions during the lockdown should be addressed to assess their impact on mental health, aspects that were not afforded due to length limitations of the study. The last limitation to be considered is that classes explained a medium percentage of the textual units. Thus, these results should be confirmed with further research.

In summary, this situation of lockdown has led to major problems in teachers' lives, as evidenced by the pressure that online educational methods have placed on them: many hours of work and difficulties due to the lack of physical contact or due to the obstacles created on combining personal life with family. 
TABLE 5 | Information of Question 3: "What changes do you see in your interpersonal relationships? How do you feel about it?"

\begin{tabular}{|c|c|c|c|c|c|}
\hline Class & $\chi^{2}$ & & ECU & $\%$ & Word \\
\hline \multicolumn{6}{|c|}{ Low physical activity group } \\
\hline 1 & & Need for physical contact & 47 & 49.47 & Contact [Contacto] \\
\hline \multirow[t]{3}{*}{ Sentences } & 14 & \multicolumn{4}{|c|}{ I need physical contact [necesito contacto físico] } \\
\hline & 14 & \multicolumn{4}{|c|}{ They are so virtual. I need physical contact [son tan virtuales. necesito el contacto físico] } \\
\hline & 14 & \multicolumn{4}{|c|}{$\begin{array}{l}\text { It has been increased the contact via online and sometimes overwhelms me [aumenta el contacto vía online y me agobia a } \\
\text { veces] }\end{array}$} \\
\hline 2 & & Online relationships & 20 & 21.05 & Relationship [Relación] \\
\hline \multirow[t]{3}{*}{ Sentences } & 15 & \multicolumn{4}{|c|}{$\begin{array}{l}\text { What an interpersonal relationship. The only way we communicate is through diverse electronic media. whatsapp, mail, } \\
\text { some facetime. I prefer the face to face relationship, this situation seems me very cold and unproductive [que relación } \\
\text { interpersonal. como único nos comunicamos es por medios electrónicos de diversa índole. whatsapp, mail, algún facetime. } \\
\text { prefiero la relación cara a cara, esta situación me parece muy fría y poco productiva] }\end{array}$} \\
\hline & 7 & \multicolumn{4}{|c|}{$\begin{array}{l}\text { I begin to consider the importance and need of some interpersonal relationships, to value some and lose interest in others } \\
\text { [empiezo a plantearme la importancia y necesidad de algunas relaciones interpersonales, a valorar algunas y } \\
\text { desinteresarme por otras] }\end{array}$} \\
\hline & 7 & \multicolumn{4}{|c|}{$\begin{array}{l}\text { Changes in relationships, they have become phone or videoconference relationships. Not totally satisfied, I prefer } \\
\text { face-to-face relationships [cambios en las relaciones, han pasado a ser telefónicas o por videoconferencia. no totalmente } \\
\text { satisfecha, prefiero presencial] }\end{array}$} \\
\hline 3 & & Distance relationships & 15 & 15.79 & To like [Gusta] \\
\hline \multirow[t]{3}{*}{ Sentences } & 21 & \multicolumn{4}{|c|}{$\begin{array}{l}\text { I don't miss anyone. I like social distance. In fact, I don't care about social and nobody complains because it is normal [no } \\
\text { echo de menos a nadie. me gusta la distancia social. de hecho, paso de lo social y nadie se queja porque es lo normal] }\end{array}$} \\
\hline & 14 & \multicolumn{4}{|c|}{ I would like to dedicate to them more time [me gustaría dedicarles más tiempo] } \\
\hline & 10 & \multicolumn{4}{|c|}{$\begin{array}{l}\text { Better. Because I have free time and I'm not overwhelmed by work and distance [mejor. por-que tengo tiempo libre y no } \\
\text { estoy agobiada por el trabajo y la distancia] }\end{array}$} \\
\hline 4 & & Distance with friends & 13 & 13.69 & My [Mis] \\
\hline \multirow[t]{3}{*}{ Sentences } & 12 & \multicolumn{4}{|c|}{$\begin{array}{l}\text { I feel further far away from my friends and colleagues. Lockdown is getting us away little by little [me siento más alejada de } \\
\text { mis amigos y compañeros. el confinamiento nos está alejando poco-a-poco] }\end{array}$} \\
\hline & 12 & \multicolumn{4}{|c|}{ Wanting to see my friends [con ganas de ver a mis amigos] } \\
\hline & 6 & \multicolumn{4}{|c|}{$\begin{array}{l}\text { I feel good, I keep talking to both my friends and my girlfriend on a daily basis and I try to make video calls regularly [me } \\
\text { siento bien, sigo hablando tanto con mis amigos como con mi novia a diario e intento hacer videollamadas con regularidad] }\end{array}$} \\
\hline
\end{tabular}

\section{High physical activity group}

\section{1}

Sentences

2

Sentences

Sentences

\section{Difficulties to contact friends}

10
A [un]

Dependence on social networks. Not knowing for sure how to receive a written message in the working groups. Stressed by videoconferences [la dependencia de las redes sociales. no saber con certeza como se recibe un mensaje escrito en los grupos de trabajo. estresada en las videoconferencias]

Communication is not easy. After working all day online, you don't feel like continuing to depend on an electronic device to talk to others [no es fácil comunicarse. después de estar todo el día trabajando online no apetece seguir dependiendo de un aparato electrónico para hablar más]

Sometimes a little far away from friends and parents because I don't visit them as much as I would like [A veces un poco alejada de amigos y padres porque no los visito tanto como quisiera]
Quality of interpersonal relationships
11
20.00
Need [Necesidad]

6 We value more those who have always been there and you need to see them. I feel nostalgic [que valoramos más a quienes siempre han estado ahi y tienes la necesidad de verlos. me. siento nostálgica]

6 Less and less contact, less joy and I feel sad [cada vez menos contacto, menos alegría y me siento triste]

3 I feel good, because I am satisfied with my interpersonal relationships and the relationship remains the same, we remain the same [me siento bien, porque estoy satisfecha con mis relaciones interpersonales y la relación sigue siendo la misma, seguimos igual]

Greater contact

10

18.18

My [Mis]

21 It is strange to talk to my neighbors or to someone apart from my partner and children. I miss my other family and friends [se me hace extraño hablar con mis vecinos o con alguien al margen de mi pareja e hijos. echo de menos a mi demás familia y amigos]

15 I have more time to talk to my friends and I see more often my family, so this point has been positive [tengo más tiempo para hablar con mis amigos y veo más a la familia, así-que este punto ha sido positivo]

11 they have improved, I even talk to my parents more often than I ever did before [han mejorado, incluso hablo con mis padres más de lo que lo hacía antes] 
TABLE 5 | Continued

\begin{tabular}{|c|c|c|c|c|c|}
\hline Class & $\chi^{2}$ & & ECU & $\%$ & Word \\
\hline 4 & & Greater online contact & 24 & 43.64 & Family member [Familiar] \\
\hline \multirow[t]{3}{*}{ Sentences } & 10 & \multicolumn{4}{|c|}{$\begin{array}{l}\text { More disagreements as there is much more contact and less time for outdoor activities [más roce al haber mucho más } \\
\text { contacto y menos tiempo para actividades al aire libre] }\end{array}$} \\
\hline & 10 & \multicolumn{4}{|c|}{$\begin{array}{l}\text { I make long calls with family and colleagues; these usually combine professional and personal aspects. We usually make a } \\
\text { video call with friends, but personal direct contact is missed [hago largas llamadas con familiares y con colegas; en estas se } \\
\text { suelen compaginar aspectos profesionales y personales. con los amigos solemos hacer alguna videollamada, pero el } \\
\text { contacto personal se echa de menos] }\end{array}$} \\
\hline & 6 & \multicolumn{4}{|c|}{$\begin{array}{l}\text { I have more contact than before with some people thanks to the free time of both and the social networks [hay personas } \\
\text { con las que ahora contacto más-que antes gracias al tiempo libre de ambos y a las redes sociales] }\end{array}$} \\
\hline
\end{tabular}

Obviously, we will have to learn from this experience in several ways. On the one hand, it is essential to study which digital competences both teachers and students have, as well as parents, since in the vast majority of cases, they have had to act as a bridge to facilitate the teaching-learning process of their children (Cuetos et al., 2020). This is already invariable whether the health requirements force a new lockdown or not. On the other hand, the situation created by the COVID-19 pandemic disease has evidenced the advantages of online training and its drawbacks because it can help in expanding borders and bringing education to every home. But for this to become possible, many limitations, mostly technical (lack of computers, not enough for all family members, inadequate or non-existent internet connections), have to be overcome as teachers' concerns have manifested, which will have to be taken into account by universal digitization policies, by the rulers, and by public policies that prevent the digital gap. Other limitations could be those related to knowledge and skills, and teachers have mentioned that they might have to be trained in the didactic and instructional value that each resource and each strategy has, since there is not a direct translation from what is done in the classroom to what has to be done online. Considering this difficult situation, it is also necessary to design better-structured teacher training plans, which do not generate an excessive workload, as it has been reflected in the results of this research. Obviously, no one was prepared to make the leap from classroom to online teaching from 1 day to another.

Another point that should be considered is that in some countries, as in the case of Spain, the hardest moment of lockdown prevented from leaving home except for very justified reasons. Therefore, it is not surprising to find out low physical activity scores. Given the importance that physical activity has in mental health (Fuentes-Barria et al., 2018), it would be convenient to establish support programs to encourage physical activity for similar situations in the future, in the case that health requirements force citizens to return to lockdown.

In conclusion, the hard lesson that has involved alleviating the difficult situation of the pandemic disease leads to three action

\section{REFERENCES}

Amatriain-Fernández, S., Murillo-Rodríguez, E. S., Gronwald, T., Machado, S., and Budde, H. (2020). Benefits of physical activity and physical exercise in points: the establishment of measures to facilitate the online teaching resources; the design of teaching strategies that favor teaching-learning processes based on blended or online methods; and the development of support programs to foster physical activity among citizens.

\section{DATA AVAILABILITY STATEMENT}

The datasets presented in this article are not readily available because we didn't ask participants any permission and informed consent to share the data. Requests to access the datasets should be directed to taguirre@ull.edu.es.

\section{ETHICS STATEMENT}

The studies involving human participants were reviewed and approved by Universidad de La Laguna ULL. The patients/participants provided their written informed consent to participate in this study.

\section{AUTHOR CONTRIBUTIONS}

Authors in this manuscript contributed as stated in this section. On the one hand, LA, LC, TA, and ÁB were involved in the conceptualization of the project and in the acquisition of the data. On the other hand, EV and ÁB were involved in the analysis and interpretation of the data. Finally, all authors were involved in the drafting and revision of the work for intellectual content, provided approval for submission of the contents for publication, and agreed to be accountable for the accuracy and integrity of the project.

\section{ACKNOWLEDGMENTS}

The authors would like to acknowledge the participants of this study for their valuable collaboration.

the time of pandemic. Psychol. Trauma Theory Res. Prac. Pol. 12, S264-S266. doi: $10.1037 /$ tra0000643

Asmundson, G. J. G., and Taylor, S. (2020). Coronaphobia: fear and the 2019-nCoV outbreak. J. Anxiety Disord. 70:102196. doi: 10.1016/j.janxdis.2020.102196 
Bao, Y., Sun, Y., Meng, S., Shi, J., and Lu, L. (2020). 2019-nCoV epidemic: address mental health care to empower society. Lancet 22, e37-e38. doi: 10.1016/S0140-6736(20)30309-3

Bauer, M. W. (2003). Análisis de textos asistidos con programas computacionales. Subjetividad y Procesos Cognitivos 3, 101-112. Available online at: http://dspace. uces.edu.ar:8180/xmlui/handle/123456789/516

Bogaert, I., De Martelaer, K., Deforche, B., Clarys, P., and Zinzen, E. (2014). Associations between different types of physical activity and teachers' perceived mental, physical, and work-related health. BMC Public Health 14:534. doi: 10.1186/1471-2458-14-534

Camargo, B., and Bousfield, A. (2009). Social representations, risk behaviors and AIDS. Span. J. Psychol. 12, 565-575. doi: 10.1017/S1138741600 001931

Creswell, J. W., and Plano Clark, V. L. (2011). Designing and Conducting Mixed Methods Research. Los Angeles, CA: Sage.

Cuetos, M. J., Grijalbo, L., Argüeso, E., Escamilla, V., and Ballesteros, R. (2020). Potencialidades de las TIC y su papel fomentando la creatividad: percepciones del profesorado. Revista Iberoamericana de Educación a Distancia, 23, 287-306. doi: $10.5944 /$ ried.23.2.26247

Daniel, S. J. (2020). Education and the COVID-19 pandemic. Prospects. doi: 10.1007/s11125-020-09464-3

De Alba, M. (2004). El método de ALCESTE y su utilización al estudio de las representaciones sociales del espacio urbano: el caso de la Ciudad de México. Textes sur les Représentations Sociales 13, 1.2-1.20. Available online at: http:// psr.iscte-iul.pt/index.php/PSR/article/view/357

Denscombe, M. (2008). Communities of practice a research paradigm for the mixed methods approach. J. Mixed Methods Res. 2, 270-283. doi: $10.1177 / 1558689808316807$

Education and Youth Policy Analysis Unit in the Education Audiovisual and Culture Executive Agency (2020a). Organization of Primary Education. Available online at: https://eacea.ec.europa.eu/nationalpolicies/eurydice/content/organisation-primary-education-42_en (accessed June 5, 2020)

Education and Youth Policy Analysis Unit in the Education Audiovisual and Culture Executive Agency (2020b). Organization of General Lower Secondary Education. Available online at: https:/eacea.ec.europa.eu/national-policies/ eurydice/content/organisation-general-lower-secondary-education-33_en (accessed June 5, 2020)

Education and Youth Policy Analysis Unit in the Education Audiovisual and Culture Executive Agency (2020c). Initial Education for Teachers Working in Early Childhood and School Education. Available online at: https://eacea. ec.europa.eu/national-policies/eurydice/content/initial-education-teachersworking-early-childhood-and-school-education-78_en (accessed June 5, 2020)

European Agency for Special Needs and Inclusive Education. (n.d.). European Agency Coronavirus (COVID-19) Precautions and Measures. Available online at: https://www.european-agency.org/news/europeanagency-coronavirus-covid-19-precautions-and-measures (accessed June 5, 2020)

Fuentes-Barria, H. A., González, C. A., and Aguilera, R. A. (2018). Trastornos de salud mental y terapias deportivas. Revisión narrativa. Horiz. Enferm., 29, 26-33. doi: 10.7764/Horiz_Enferm.29.1.26-33

Inter-Agency Standing Committee (2007a). IASC guidelines on mental health and psychosocial support in emergency settings. Available online at: Available online at: https://interagencystandingcommittee.org/system/files/legacy_files/ guidelines_iasc_mental_health_psychosocial_june_2007.pdf (accessed June 5, 2020)

Inter-Agency Standing Committee (2007b). Action Sheet 7.1 Strengthen access to safe and supportive education. In IASC Guidelines on Mental Health and Psychosocial Support in Emergency Settings. Available online at: https:// interagencystandingcommittee.org/system/files/legacy_files/guidelines_iasc_ mental_health_psychosocial_june_2007.pdf (accessed June 5, 2020)

JASP Team (2020). JASP (Version 0.12.2) [Computer software].

Johnson, R. B., and Onwuegbuzie, A. J. (2004). Mixed methods research: a research paradigm whose time has come. Educ. Res. 33, 14-26. doi: 10.3102/0013189X033007014

Kwan, B. M., Davis, K. J., and Dunn, A. L. (2012). "Physical activity for the prevention of depression," in Physical Activity Across the Lifespan
Issues in Children's and Families' Lives, vol 12. eds A. Meyer, and T. Gullotta (New York, NY: Springer). 97-119. doi: 10.1007/978-1-46143606-5_6

Liu, D., Ren, Y., Yan, F., Li, Y., Xu, X., Yu, X., et al. (2020). Psychological impact and predisposing factors of the coronavirus disease 2019 (COVID-19) pandemic on general public in China. Lancet Psychiatry [Preprint]. doi: 10.2139/ssrn.35 51415

Mahase, E. (2020). Covid-19: mental health consequences of pandemic need urgent research, paper advises. BMJ 369:m1515. doi: 10.1136/bmj. $\mathrm{m} 1515$

Orte, C., Ballester, Ll., and Nevot-Caldentey, Ll. (2020). Apoyo familiar ante el covid-19 en españa [Family support against covid-19]. Scielo Preprints. doi: 10.1590/SciELOPreprints.297 (accessed May 3, 2020).

Ozamiz-Etxebarria, N., Idoiaga Mondragon, N., Dosil Santamaría, M., and Picaza Gorrotxategi, M. (2020). Psychological symptoms during the two stages of lockdown in response to the covid-19 outbreak: an investigation in a sample of citizens in northern Spain. Front. Psychol. 11:1491. doi: $10.3389 /$ fpsyg.2020.01491

Rajkumar, R. P. (2020). COVID-19 and mental health: a review of the existing literature. Asian J. Psychiatry 52:102066. doi: 10.1016/j.ajp.2020. 102066

Reinert, M. (2001). Alceste, une méthode statistique et sémiotique d'analyse de discours; application aux "Rêveries du promeneur solitaire. Revue française Psychiatrie Psychol Méd 49, 32-36.

Rodríguez-Rey, R., Garrido-Hernansaiz, H., and Collado, S. (2020). Psychological impact and associated factors during the initial stage of the coronavirus (COVID-19) pandemic among the general population in Spain. Front. Psychol. 11:1540. doi: 10.3389/fpsyg.2020. 01540

Ruiz, F. J., García-Beltrán, D. M., and Suárez-Falcón, J. C. (2017). General health questionnaire-12 validity in colombia and factorial equivalence between clinical and nonclinical participants. Psychiatry Res. 256, 53-58. doi: $10.1016 /$ j.psychres.2017.06.020

Sánchez-López, M. P., and Dresch, V. (2008). The 12-item general health questionnaire (GHQ-12): Reliability, external validity and factor structure in the Spanish population. Psicothema 20, 839-843. Available online at: http://www.psicothema.com/psicothema.asp? id $=3564$

Santillán, W. (2020). El teletrabajo en el Covid-19. CienciAmérica, 9, 65-76. doi: $10.33210 /$ ca.v9i2.289

Slimani, M., Paravlic, A. H., Mbarek, F., Bragazzi, N. L., and Tod, D. (2020). The relationship between physical activity and quality of life during the confinement induced by COVID-19 outbreak: a pilot study in Tunisia. Front. Psychol. 11:1882. doi: 10.3389/fpsyg.2020. 01882

Smith, T. M., Cannata, M., and Haynes, K. T. (2016). Reconciling data from different sources: Practical realities of using mixed methods to identify effective high school practices. Teachers College Record 118, 1-34. Available online at: https://www.tcrecord.org/content.asp? contentid=20515

UNESC. (2020c). Adverse Consequences of School Closures. Available online at: https://en.unesco.org/covid19/educationresponse/consequences (accessed June 5, 2020)

UNESCO (2020a). TVET Systems and Labour Markets. UNESCO COVID-19 Education Response, 5.2. Available online at: https://unesdoc.unesco.org/ark:/ 48223/pf0000373274 (accessed June 5, 2020)

UNESCO (2020b). Education: From Disruption to Recovery. Available online at: https://en.unesco.org/covid19/educationresponse/ (accessed June 5, 2020)

UNESCO (2020d). COVID-19 Webinar: A New World for Teachers, Education's Frontline Workers - COVID-19 Education Webinar \#2. Available online at: https://en.unesco.org/news/covid-19-webinar-new-world-teacherseducations-frontline-workers-covid-19-education-webinar-2 (accessed June 5, 2020)

UNESCO (2020e). COVID-19 Crisis And Curriculum: Sustaining Quality Outcomes In The Context Of Remote Learning. UNESCO COVID-19 Education Response, 4.2. Available online at: https://unesdoc.unesco.org/ark:/48223/pf0000373273? posInSet=3andqueryId=5f03ab97-4ae4-4d8d-bf9f-3113d4d9a294 (accessed June 5, 2020) 
Wang, C., and Zhao, H. (2020). The Impact of COVID-19 on Anxiety in Chinese University Students. Front. Psychol. 11:1168. doi: 10.3389/fpsyg.2020.01168

Zhang, S. X., Wang, Y., Rauch, A., and Wei, F. (2020). Unprecedented disruption of lives and work: Health, distress and life satisfaction of working adults in China one month into the COVID-19 outbreak. Psychiatry Res. 288:112958. doi: 10.1016/j.psychres.2020.112958

Conflict of Interest: The authors declare that the research was conducted in the absence of any commercial or financial relationships that could be construed as a potential conflict of interest.
The reviewer NI declared a shared affiliation with several of the authors, LA, LC, to the handling editor at time of review.

Copyright (๑) 2020 Aperribai, Cortabarria, Aguirre, Verche and Borges. This is an open-access article distributed under the terms of the Creative Commons Attribution License (CC BY). The use, distribution or reproduction in other forums is permitted, provided the original author(s) and the copyright owner(s) are credited and that the original publication in this journal is cited, in accordance with accepted academic practice. No use, distribution or reproduction is permitted which does not comply with these terms. 